\title{
The Inhibitory Effect of Capparis Ovata Polysaccharides on Cultured Pterygium Fibroblasts
}

\author{
Erkut Kucuk, ${ }^{1}$ 이 Isil Aydemir, ${ }^{2}$ (i) Kursad Zor, ${ }^{1}$ (i) Oktay Ozkan ${ }^{3}$
}

1Department of Ophthalmology, Nigde Omer Halisdemir University Faculty of Medicine, Nigde, Turkey

${ }^{2}$ Department of Histology and Embryology, Nigde Omer Halisdemir University, Faculty of Medicine, Nigde, Turkey

${ }^{3}$ Department of Pharmacology, Nigde Omer Halisdemir University Faculty of Medicine, Nigde, Turkey

\begin{abstract}
Objectives: Pterygium recurrence after removal surgery is an important problem. Polysaccharides obtained from Capparis species have been shown to possess various biological properties, including anti-tumor activity. This study was an investigation of the effect of Capparis ovata polysaccharides on cultured pterygium fibroblasts and a comparison with the effects of mitomycin C (MMC).

Methods: Pterygium tissue samples were obtained during excision surgery from 3 patients with primary pterygium, and fibroblasts were isolated. Pterygium fibroblast cultures and L929 cell cultures were treated with different concentrations of MMC and Capparis ovata polysaccharides. Cell proliferation and migration were evaluated.

Results: An MTT assay revealed that cell viability decreased with increasing concentrations of Capparis ovata polysaccharides in both cell types. MMC also inhibited the proliferation of both cell types. A scratch-wound assay indicated that both Capparis ovata polysaccharides and MMC molecules reduced proliferation and migration in the pterygium fibroblasts and L929 cells.

Conclusion: The in vitro Capparis ovata polysaccharide inhibition of proliferation and migration of pterygium fibroblasts was similar to that of MMC. The results of this study suggested that Capparis ovata polysaccharides may be a valuable candidate drug to treat pterygium.
\end{abstract}

Keywords: Capparis ovata, fibroblast, mitomycin C, polysaccharide, pterygium

\section{Introduction}

Pterygium is an ocular surface disease in which conjunctival tissue proliferates and extends onto the cornea. The prevalence has been reported to be around $10 \%$ worldwide, with geographical variation, and is slightly more prevalent in males $(1,2)$. The pathogenesis of pterygium has been investigated in many studies, but the precise underlying mechanism is still unknown (3-5). Several risk factors are thought to be important in the pathogenesis of pterygium. Many studies have suggested that ultraviolet (UV) light may be a major factor in pterygium development (6-9). UV light is thought to cause oxidative stress and genetic damage, which triggers activation of inflammatory pathways and the release of growth factors that are important in the pathogenesis of pterygium (5). Pterygium can result in decreased visual acuity and may

How to cite this article: Kucuk E, Aydemir I, Zor K, Ozkan O. The Inhibitory Effect of Capparis Ovata Polysaccharides on Cultured Pterygium Fibroblasts. Beyoglu Eye J 202I; 6(I): I-6.

Address for correspondence: Erkut Kucuk, MD. Nigde Omer Halisdemir Universitesi Tip Fakultesi, Goz Hastaliklari Anabilim Dali, Nigde, Turkey

Phone: +90 5057484290 E-mail: kucukerkut@yahoo.com

Submitted Date: August 25, 2020 Accepted Date: January 09, 2021 Available Online Date: February 11, 2021

${ }^{\circ}$ Copyright 2021 by Beyoglu Eye Training and Research Hospital - Available online at www.beyoglueye.com OPEN ACCESS This work is licensed under a Creative Commons Attribution-NonCommercial 4.0 International License. 
become inflamed, causing irritation and pain. Surgical excision and a tissue graft with either a conjunctival autograft or amniotic membrane is frequently used as treatment $(\mathrm{I} 0, \mathrm{II})$. Pterygium recurrence after surgery is an important problem. It has been proposed that fibroblasts have an important role in the recurrence of pterygium, particularly in exaggerated wound healing and uncontrolled fibrosis (I2). The use of antifibrotic agents such as mitomycin C (MMC) or fluorouracil as an adjuvant in pterygium surgery can effectively decrease the recurrence rate $(13,14)$. These molecules inhibit the proliferation of fibroblasts and induce apoptosis (15). Despite the positive effects and success rate, severe complications, including scleral thinning or necrosis, corneal ulceration, and conjunctival and scleral defects, can occur following the use of these drugs (16). The search for other molecules that could provide an antifibrotic effect without these side effects continues. Recently, plant polysaccharides with various biological properties have been studied for potential applications in medicine. The antioxidant, immunomodulatory, anti-tumor, and anti-inflammatory qualities, as well as activity promoting wound healing, of polysaccharides derived from different medicinal plants have been noted in several studies $(17,18)$. In vivo and in vitro research has examined various biological characteristics of Capparis species $(19,20)$. The caper bush, which belongs to the family Capparaceae and the genus Capparis, is one example. This plant grows naturally in many parts of Turkey as a native species. The purpose of this study was to evaluate the effect of Capparis ovata polysaccharides on pterygium fibroblasts.

\section{Methods}

\section{Cell Culture}

This study was approved by the institutional review board of Niğde Ömer Halisdemir University on June 13, 2019 (no: $2019 / 12$ ) and performed according to the tenets of Declaration of Helsinki. Informed consent was obtained from all of the participants. The pterygium samples analyzed were obtained during an excision procedure for 3 patients with primary pterygium. These samples were placed into sterile petri dishes and treated as described by Cao et al. (2I). The samples were cultured in Dulbecco's Modified Eagle's medium (DMEM) (0I-050-A; Biological Industries, Beit Haemek, Israel) containing 10\% fetal bovine serum (FBS) (SOII 3; Biochrom GmbH, Berlin, Germany), L-glutamine (XC-TI7I5; Biosera, Nuaille, France), and penicillin (100 units $/ \mathrm{mL}) /$ streptomycin (PS-B, 100 units $/ \mathrm{mL}$; Capricorn Scientific $\mathrm{GmbH}$, Ebsdorfergrund, Germany) at $37^{\circ} \mathrm{C}$ in $5 \% \mathrm{CO}_{2}$ in a humidified atmosphere. The isolated pterygium fibroblasts were passaged and the cells from the third passage were used in the study experiments. An L929 fibroblast cell line was also used for comparison. The L929 cells were cultured in DMEM media supplemented with FBS, penicillin/streptomycin, and L-glutamine. The medium was discharged every 2 days. The cells were examined with an inverted microscope (Axio; Carl Zeiss AG, Oberkochen, Germany) and images of the cells were recorded.

\section{Isolation of Polysaccharides}

Capparis ovata polysaccharides were isolated from Capparis ovata fruit in the department of pharmacology according to the method described by Lv et al. (22). The polysaccharides were homogeneously dissolved in the cell culture medium and the stock solution was passed through a microfilter 0.22 $\mu \mathrm{m}$ in diameter for sterilization.

\section{MTT Assay}

A 3-(4,5-dimethylthiazol-2-yl)-2,5-diphenyltetrazolium bromide (MTT, 20395.02, Serva Electrophoresis GmbH, Heidelberg, Germany) test was used to determine the IC50 (half maximal inhibitory concentration) dose of polysaccharides and the toxicity of MMC on pterygium fibroblasts cells and L929 cells. The pterygium fibroblasts cells and L929 cells were grown in 96 -well plates $(4.5 \times 105$ cells/well) and seeded for 24 hours. The cells were then incubated with MMC $(0$, 2, $5 \mu \mathrm{m})$, for 5 minutes, and polysaccharides $(0,10,25,50$, $100,200 \mu \mathrm{g} / \mathrm{mL}$ ) for 48 hours. The medium was discharged and fresh medium $(100 \mu \mathrm{L})$ and $10 \mu \mathrm{L}$ MTT $(5 \mathrm{mg} / \mathrm{mL}$ in distilled water) was added to the wells. The cells were incubated with $10 \mu \mathrm{L} \mathrm{MTT}\left(5 \mathrm{mg} / \mathrm{mL}\right.$ in distilled water) at $37^{\circ} \mathrm{C}$ for 4 hours. Then, the MTT medium was removed. Dimethyl sulphoxide (DMSO, A3672; AppliChem GmbH, Darmstadt, Germany) was used to dissolve the formazan salts for 10 $\mathrm{min}$. The IC50 dose of polysaccharides was defined by measuring absorbance with a UV-visible spectrophotometer multiplate reader at a wavelength of $570 \mathrm{~nm}$ (ELx800UV; BioTek Instruments Inc., Winooski, VT, USA).

\section{Cell Migration Analysis}

The cell migration rate was determined using a scratchwound assay. The pterygium fibroblasts and L929 cells were grown in a 24 -well plate $(2.5 \times 105$ cells/well) until $80 \%$ confluency was achieved. The scratch-wound model was created using a $200 \mu \mathrm{L}$ plus-shaped pipette tip (+). The cells were exposed to the IC50 dose of polysaccharides for 48 hours and MMC $(2 \mu \mathrm{m})$ for 5 minutes. Images of the scratchwound areas for each group were recorded and evaluated using ImageJ. I.47 software (US National Institutes of Health, Bethesda, MD, USA). The closure percentage of wound areas was calculated.

\section{Statistical Analysis}

Each experiment of this study was performed three times. 
The data were analyzed using repeated analysis of variance with the Tukey-Kramer multiple comparisons test. A p value of $<0.05$ was accepted as statistically significant.

\section{Results}

\section{MTT Assay}

An MTT assay was used to determine the IC50 dose of polysaccharides. The findings showed that cell viability was suppressed with increasing doses of polysaccharides (Fig. I). Since the toxic effect of MMC was very high, 2 low doses (2 and 5 $\mu \mathrm{m}$ ) of MMC were applied to the cells for 5 minutes (Fig. 2). The IC50 dose of polysaccharides was $82.22 \mu \mathrm{g} / \mathrm{mL}$ for the pterygium fibroblasts and $100.75 \mu \mathrm{g} / \mathrm{mL}$ for the $\mathrm{L} 929$ cells.

\section{Cell Migration}

The inhibitory effects of polysaccharides and MMC were analyzed using a scratch-wound assay. The IC50 dose of polysaccharides inhibited cell proliferation and delayed in vitro wound healing in both the pterygium and L929 cells in comparison with the controls. Similarly, MMC inhibited cell proliferation in both cell types. The L929 and pterygium fibroblast cells in the

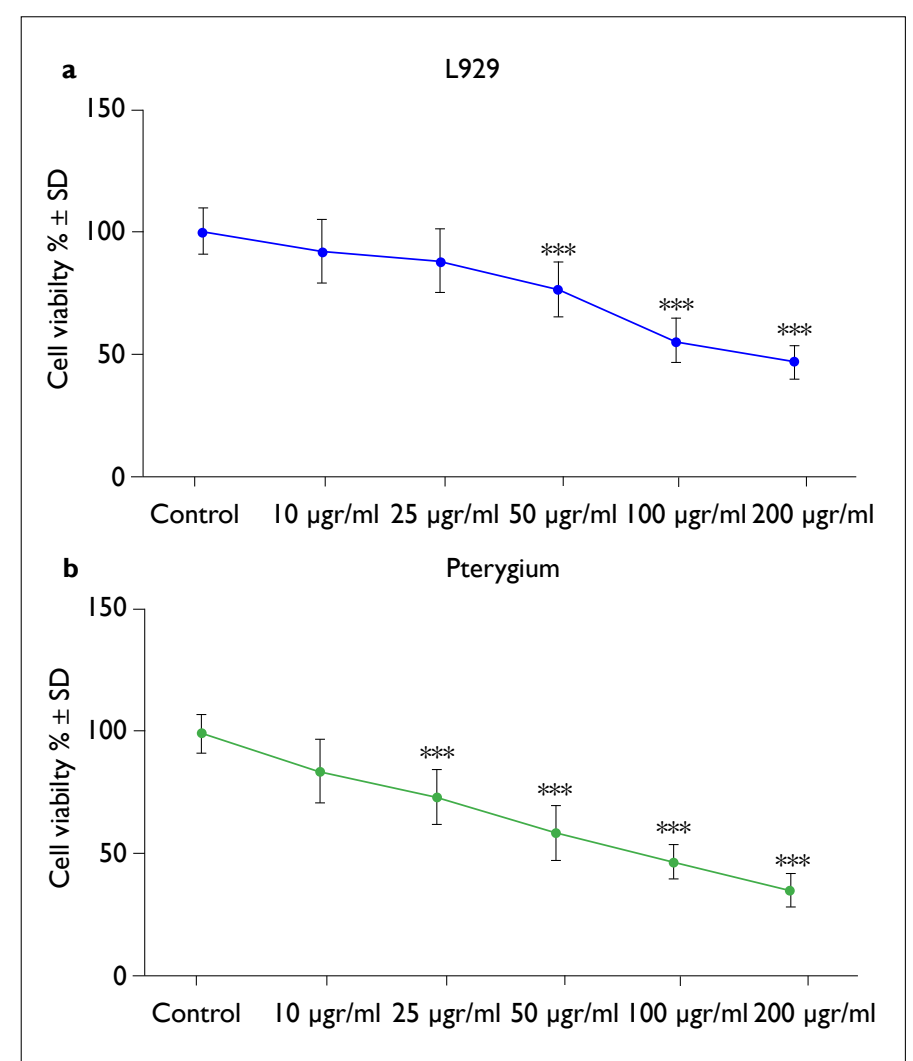

Figure I. The survival of (A) L929 and (B) pterygium cells with increasing doses of Capparis ovata polysaccharides over 48 hours was analyzed using an MTT assay. The percentage of cell survival was analyzed using one-way analysis of variance with the Tukey-Kramer multiple comparisons test $(* * * \mathrm{p}<0.00 \mathrm{I})$.

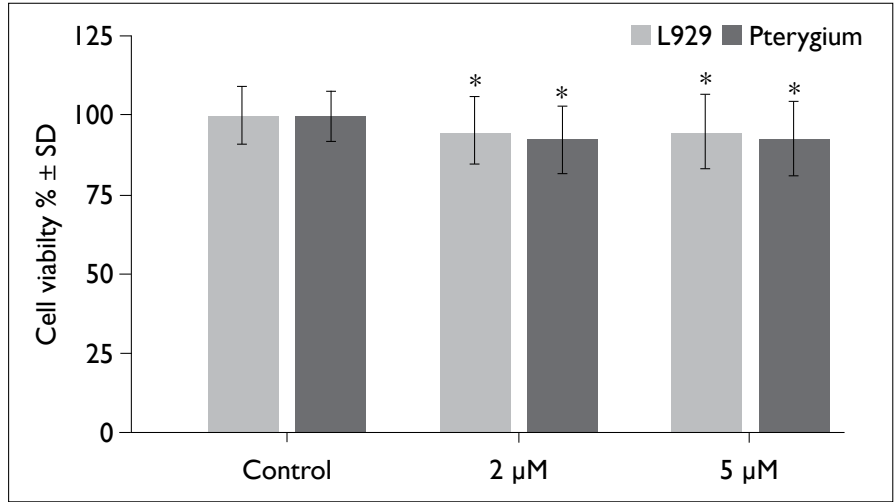

Figure 2. The survival of L929 and pterygium cells with mitomycin $\mathrm{C}$ at $2-\mu \mathrm{m}$ and $5-\mu \mathrm{m}$ doses for 5 minutes was analyzed using an MTT assay. The cell survival percentage was analyzed using one-way analysis with the Tukey-Kramer multiple comparisons test $(* p<0.05)$.

control group with no exposure to polysaccharides or MMC proliferated and migrated, and wound healing occurred after 48 hours (L929: 76.62\%, pterygium: 66.24\%; ${ }^{*}<0.05$ ) (Figs. 3-5). In the MMC-treated groups (dose of $2 \mu \mathrm{m}$ ), inhibition of proliferation of both cell types was observed and the wound site was not closed (Figs. 3, 4). The application of polysaccha-

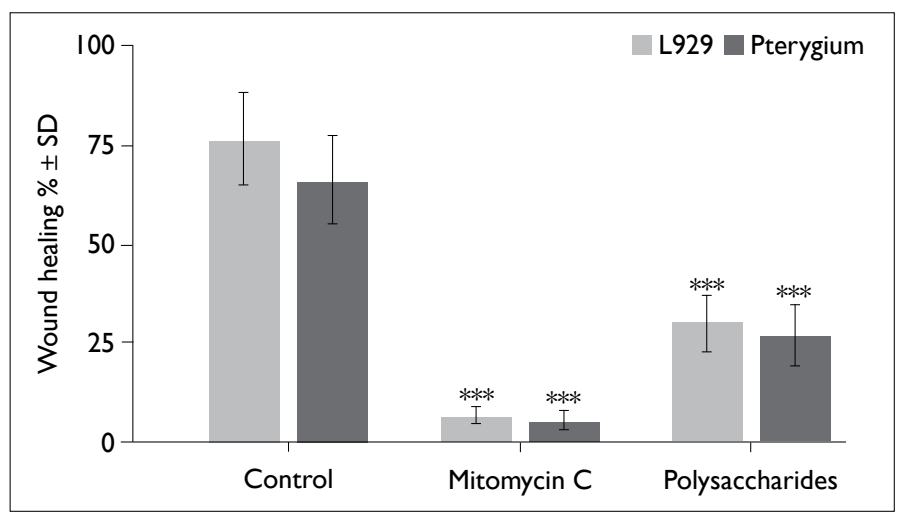

Figure 3. The percentage of wound healing with mitomycin $C(2 \mu \mathrm{m}$ for 5 minutes) and Capparis ovata polysaccharides at IC50 doses for 48 hours in the scratch-wound test area of L929 and pterygium cells.

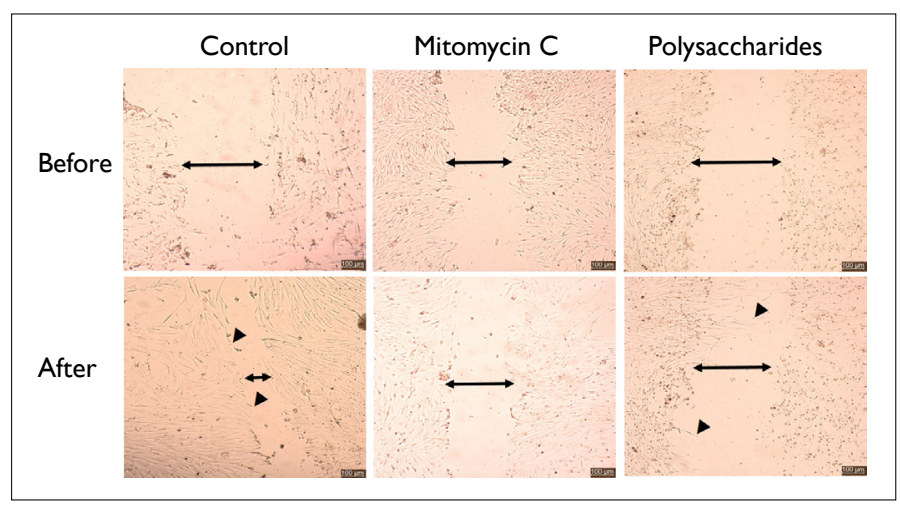

Figure 4. Pterygium fibroblast assay images indicating cell migration. Arrow heads: Migrating cells; Scale bars: $100 \mu \mathrm{m}$. 


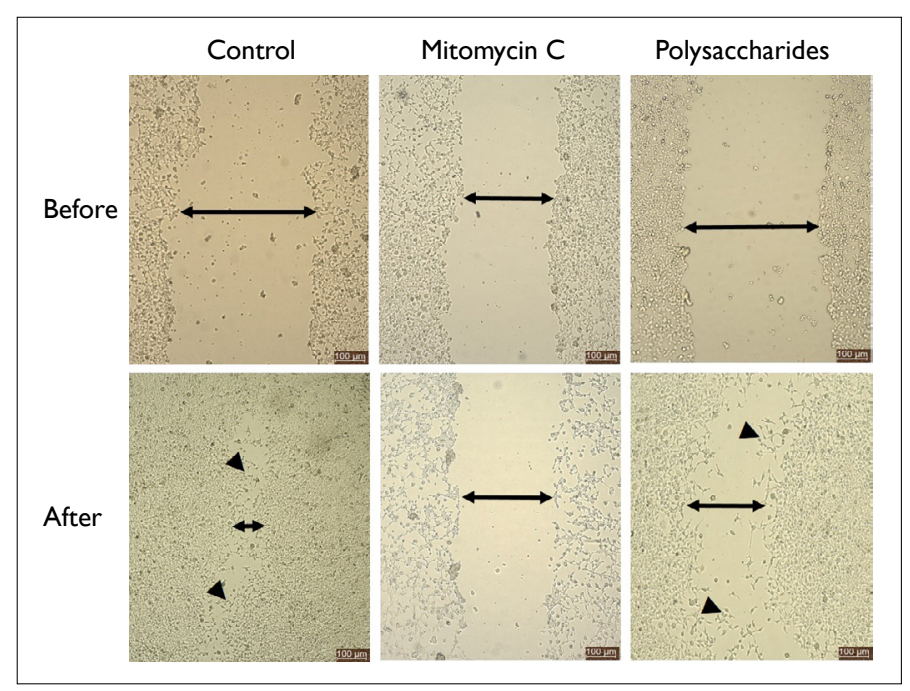

Figure 5. L929 cell-line assay images of cell migration. Arrow heads: Migrating cells; Scale bars: $100 \mu \mathrm{m}$.

rides resulted in $30.05 \%$ closure in L929 cells and $26.94 \%$ in pterygium cells $(p>0.05)$ (Figs. 3-5). Polysaccharides inhibited the proliferation of pterygium fibroblasts $(* * * p<0.00 I)$ and suppressed the cell migration in the scratch area in both cell types.

\section{Discussion}

The results of this study indicated that Capparis ovata polysaccharides effectively decreased the proliferation and migration of pterygium fibroblasts. Despite advances in therapeutic approaches, the recurrence rate after pterygium surgery is still high. Antimetabolites like MMC can decrease the recurrence rate, but may lead to severe vision-threatening complications $(16,23,24)$. Other molecules and surgical techniques continue to be investigated as a means to decrease the rate of recurrence while avoiding severe complications $(21,23,25)$.

An increasing number of studies have investigated bioactive plant polysaccharides and their biological activities on various diseases. Plant polysaccharides are reported to have various biological characteristics, such as immunomodulatory, antibiotic, antioxidant, antitumor, anticoagulant, and anti-inflammatory activity $(17,26)$. These polysaccharides are reported to be relatively nontoxic and have a low risk of significant side effects (17). They are also less expensive than synthetic products (26). Capparis ovata is a member of the family Capparaceae and the genus Capparis, which consists of 250 to 400 species. Capparis species have been reported to have diverse biological properties (27). Various extracts obtained from Capparis ovata have shown to possess antioxidant, anti-inflammatory, and antibiotic activity $(28,29)$ Polysaccharides obtained from another member of the Capparaceae family, Capparis spinosa, have been shown to inhibit the growth of tumor cells and induce tumor cell apoptosis (20,30).

Previous studies have reported that pterygium fibroblasts have transformed or preneoplastic cell properties, and fibroblast proliferation and invasion of the cornea by fibroblasts has been suggested as the main mechanism of pterygium pathogenesis $(3 \mathrm{I}, 32)$. Based on the results of previous studies studying the molecules obtained from Capparis species, we investigated the effect of polysaccharides obtained from Capparis ovata on pterygium fibroblast and L929 cell cultures. A dose-dependent decrease in cell viability in both cell types was seen in an MTT assay and decreased proliferation and migration of the cells was observed in a scratch-wound assay with Capparis ovata polysaccharides. MMC is frequently used for 3 to 5 minutes during pterygium surgery (33). Since it is very toxic, MMC is frequently used for 5 minutes in cell cultures in experimental settings $(21,25)$. We also used MMC in low concentrations and for a short duration (5 minutes) in the current study. As seen in previous studies using MMC in various cell cultures, we saw decreased cell viability in the MTT assay and a significant decrease in cell migration and proliferation in a scratch-wound assay in both cell types using MMC. The L929 fibroblast cell line is commonly used to evaluate the cytotoxicity of molecules and other materials (34-36). We used the L929 fibroblast cell line as a control in our study to evaluate the effect of Capparis ovata polysaccharides. The Capparis ovata polysaccharides inhibited the proliferation and migration of L929 cells, however, the IC50 value of Capparis ovata polysaccharides was higher for the L929 cells in comparison with the pterygium fibroblasts in our study. This may prove useful in the management of pterygium since a lower dose of the drug may be applied with an adequate effect on pterygium fibroblasts with less potentially toxic effect on normal cells.

Interpretation of the findings of this study may be limited by some design elements. First, the results of this in vitro experimental study cannot be applied directly in clinical practice. In vivo studies using animals could be helpful in this respect, but a reliable animal model of pterygium is still lacking. In addition, we used the L929 fibroblast cell line as a control in this study, rather than human conjunctival fibroblasts, but the L929 cell line is frequently used in toxicology studies and is an acceptable alternative control cell type in an experimental study.

In conclusion, this research evaluated the antiproliferative activities of Capparis ovata polysaccharides on pterygium fibroblasts. The data from this study revealed that Capparis ovata polysaccharides inhibited the proliferation and migration of pterygium fibroblasts in vitro. Lower toxicity and cost suggest that plant polysaccharides could be potentially valuable therapeutic agents for several diseases. Our results indicate that Capparis ovata polysaccharides may be a candidate for the treatment of pterygium, but further studies are necessary to clearly define their potential. 


\section{Disclosures}

Ethics Committee Approval: Niğde Ömer Halisdemir University Ethics Committee No: 2019/I2 Date: 13.06.2019.

Peer-review: Externally peer-reviewed.

Conflict of Interest: None declared.

Authorship Contributions: Involved in design and conduct of the study (EK, IA, KRZ, OO); preparation and review of the study (EK, IA, KRZ, OO); data collection (EK, IA, KRZ, OO); and statistical analysis $(E K, I A)$.

\section{References}

I. Liu L, Wu J, Geng J, Yuan Z, Huang D. Geographical prevalence and risk factors for pterygium: a systematic review and meta-analysis. BMJ open 2013;3:e003787. [CrossRef]

2. Droutsas K, Sekundo W. Epidemiology of pterygium. A review. Ophthalmologe 2010;107:5II-2, 4-6. [CrossRef]

3. Liu T, Liu Y, Xie L, He X, Bai J. Progress in the pathogenesis of pterygium. Curr Eye Res 2013;38:1 191-7. [CrossRef]

4. Bradley JC, Yang W, Bradley RH, Reid TW, Schwab IR. The science of pterygia. Br J Ophthalmol 2010;94:815-20. [CrossRef]

5. Di Girolamo N, Chui J, Coroneo MT, Wakefield D. Pathogenesis of pterygia: role of cytokines, growth factors, and matrix metalloproteinases. Prog Retin Eye Res 2004;23:195-228. [CrossRef]

6. Taylor HR. Corneal changes associated with chronic UV irradiation. Arch Ophthalmol 1989;107:148I-4. [CrossRef]

7. Oliva MS, Taylor H. Ultraviolet radiation and the eye. Int Ophthalmol Clin 2005;45:I-17.

8. Sherwin JC, Hewitt AW, Kearns LS, Griffiths LR, Mackey DA, Coroneo MT. The association between pterygium and conjunctival ultraviolet autofluorescence: the Norfolk Island Eye Study. Acta Ophthalmol 2013;91:363-70. [CrossRef]

9. McKnight CM, Sherwin JC, Yazar S, Forward H, Tan AX, Hewitt $\mathrm{AW}$, et al. Pterygium and conjunctival ultraviolet autofluorescence in young Australian adults: the Raine study. Clin Exp Ophthalmol 2015;43:300-7. [CrossRef]

10. Clearfield E, Muthappan V, Wang X, Kuo IC. Conjuncti-val autograft for pterygium. Cochrane Database Syst Rev 2016;2:CD0I I349. [CrossRef]

II. Toker E, Eraslan M. Recurrence after primary pterygium ex- cision: amniotic membrane transplantation with fibrin glue versus conjunctival autograft with fibrin glue. Curr Eye Res 2016;41:18. [CrossRef]

12. Kim KW, Park SH, Kim JC. Fibroblast biology in pterygia. Exp Eye Res 2016;142:32-9. [CrossRef]

13. Zada M, Pattamatta U, White A. Modulation of fibroblasts in conjunctival wound healing. Ophthalmology 20।8; I25:179-92.

14. Zeng W, Liu Z, Dai H, Yan M, Luo H, Ke M, et al. Anti-fibrotic, anti-VEGF or radiotherapy treatments as adjuvants for pterygium excision: a systematic review and network meta-analysis. BMC Ophthalmol 2017;17:211. [CrossRef]

15. Crowston JG, Akbar AN, Constable PH, Occleston NL, Dan- iels JT, Khaw PT. Antimetabolite-induced apoptosis in Tenon's capsule fibroblasts. Invest Ophthalmol Vis Sci 1998;39:449-54.

16. Nuzzi R, Tridico F. How to minimize pterygium recurrence rates: clinical perspectives. Clin Ophthalmol 2018;12:2347-62.

17. Xie JH, Jin ML, Morris GA, Zha XQ, Chen HQ, Yi Y, et al. Advances on bioactive polysaccharides from medicinal plants. Crit Rev Food Sci Nutr 2016;56 Suppl I:S60-84. [CrossRef]

18. Li Q, Niu Y, Xing P, Wang C. Bioactive polysaccharides from natural resources including Chinese medicinal herbs on tissue repair. Chinese Medicine 2018; 13:7. [CrossRef]

19. Ji YB, Dong F, Lang L, Zhang LW, Miao J, Liu ZF, et al. Optimization of synthesis, characterization and cytotoxic activity of Seleno-Capparis spionosa L. polysaccharide. Int J Mol Sc 2012;13:17275-89. [CrossRef]

20. Ji YB, Dong F, Ma DB, Miao J, Jin LN, Liu ZF, et al. Optimizing the extraction of anti-tumor polysaccharides from the fruit of Capparis spionosa L. by response surface methodology. Molecules 20 I2; 17:7323-35. [CrossRef]

21. Cao D, Chu WK, Ng TK, Yip YWY, Young AL, Pang CP, Jhanji $\mathrm{V}$. Cellular proliferation and migration of human pterygium cells: Mitomycin versus small-molecule inhibitors. Cornea 2018;37:760-6. [CrossRef]

22. Lv Y, Yang $X$, Zhao Y, Ruan Y, Yang Y, Wang Z. Separation and quantification of component monosaccharides of the tea polysaccharides from Gynostemma pentaphyllum by HPLC with indirect UV detection. Food Chemistry 2009; I 1 2:742-6. [CrossRef]

23. Kaufman SC, Jacobs DS, Lee WB, Deng SX, Rosenblatt MI, Shtein RM. Options and adjuvants in surgery for pterygium: a report by the American Academy of Ophthalmology. Ophthalmology 2013;120:20I-8. [CrossRef]

24. Lindquist TP, Lee WB. Mitomycin C-associated scleral stromalysis after pterygium surgery. Cornea 2015;34:398-40I. [CrossRef]

25. Lee $\mathrm{H}$, Jeong $\mathrm{H}$, Lee CM, Shin JA, Jang SW, Lee JH, et al. Antifibrotic effects of sakuraso-saponin in primary cultured pterygium fibroblasts in comparison with mitomycin c. Invest Ophthalmol Vis Sci 2019;60:4784-91. [CrossRef]

26. Liu J, Willför S, Xu C. A review of bioactive plant polysaccharides: Biological activities, functionalization, and biomedical applications. Bioact Carbohydr Diet Fibre 2015;5:3I-6I. [CrossRef]

27. Arslan R, Bektas N, Ozturk Y. Antinociceptive activity of methanol extract of fruits of Capparis ovata in mice. J Ethnopharmacol 2010;|31:28-32. [CrossRef]

28. Bektas N, Arslan R, Goger F, Kirimer N, Ozturk Y. Investigation for anti-inflammatory and anti-thrombotic activities of methanol extract of Capparis ovata buds and fruits. J Ethnopharmacol 2012; 142:48-52. [CrossRef]

29. Okur M, Ayla S, Cicek Polat D, Gunal M, Yoltas A, Biçeroğlu Ö. Novel insight into wound healing properties of methanol extract of Capparis ovata Desf. var. palaestina Zohary fruits. J Pharm Pharmacol 2018;70:140I-13. [CrossRef]

30. Ji Y, Dong F, Gao S, Yu M. Study on Capparis spionosa L polysac- 
charide (CSPS) induced HepG2 apoptosis by controlling Ca2+ path. Adv Mat Res 201 I;282:203-8. [CrossRef]

3I. Chen JK, Tsai RJ, Lin SS. Fibroblasts isolated from human pterygia exhibit transformed cell characteristics. In vitro cellular \& developmental biology. Animal 1994;30a:243-8. [CrossRef]

32. Cameron ME. Histology of pterygium: an electron microscopic study. Br J Ophthalmol 1983;67:604-8. [CrossRef]

33. Martins TG, Costa AL, Alves MR, Chammas R, Schor P. Mitomycin $C$ in pterygium treatment. Int J Ophthalmol 2016;9:4658.
34. Yang P, Zhang DD, Wang ZZ, Liu HZ, Shi QS, Xie XB. Copper(ii) complexes with NNO ligands: synthesis, crystal structures, DNA cleavage, and anticancer activities. Dalton Trans 2019;48: I7925-35. [CrossRef]

35. Malakpour Permlid A, Roci P, Fredlund E, Fält F, Önell E, Johansson $\mathrm{F}$, et al. Unique animal friendly 3D culturing of human cancer and normal cells. Toxicol In Vitro 2019;60:5I-60. [CrossRef]

36. Ehlert M, Roszek K, Jędrzejewski T, Bartmański M, Radtke A. Titania nanofiber scaffolds with enhanced biointegration ac- tivity-preliminary in vitro studies. Int J Mol Sci 2019;20:5642. 